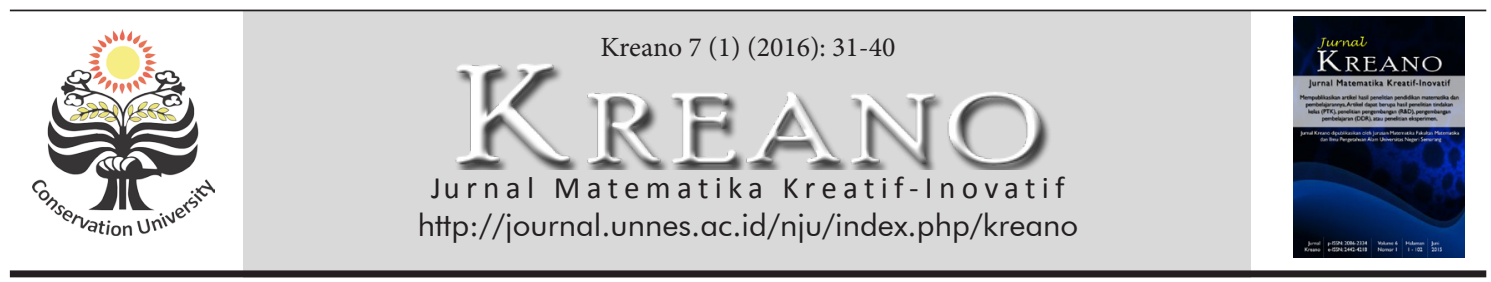

\title{
Desain Pembelajaran Materi Belah Ketupat Menggunakan Kain Jumputan Palembang untuk Siswa Kelas VII
}

\author{
Fauziyah', Zulkardi ', Ratu Ilma Indra Putri ${ }^{1}$ \\ 'Sriwijaya University, Indonesia \\ Coresponding Author Email: fauziyaharifin@yahoo.com \\ DOI: http://dx.doi.org/10.15294/kreano.v7i1.4829 \\ Received : January 2016; Accepted: March 2016; Published: June 2016
}

\begin{abstract}
Abstrak
Desain pembelajaran materi belah ketupat menggunakan kain Jumputan Palembang untuk siswa kelas VII. Penelitian ini bertujuan untuk melihat bagaimana penggunaan kain Jumputan Palembang dalam membangun pemahaman siswa mengenai belah ketupat. Siswa akan membandingkan luas daerah dua buah kain Jumputan, merancang dan membuat belah ketupat kemudian menggunting serta menyusunnya kembali menjadi suatu bentuk baru, menentukan luas daerah belah ketupat, membandingkan keliling dua buah kain Jumputan dan menentukan keliling belah ketupat. Subjek penelitian ini adalah 30 siswa kelas VII SMP Pusri Palembang. Penelitian ini menggunakan design research yang terdiri dari tiga tahap : preparing for the experiment, experiment in the classroom (pilot experiment dan teaching experiment), dan retrospective analysis. Pada tahap preparing for the experiment, beberapa aktifitas dibuat menggunakan pendekatan Pendidikan Matematika Realistik Indonesia (PMRI). Hasil dari penelitian menunjukkan kain Jumputan Palembang dapat digunakan sebagai starting point dalam pembelajaran belah ketupat untuk siswa kelas VII SMP.
\end{abstract}

\begin{abstract}
The design learning rhombus using kain Jumputan Palembang for VII grade students. This research aims to investigate how to use Kain Jumputan Palembang to build student's understanding on rhombus. Students were required to comparing the area of two cloths, designing and making rhombus then reshaping to new shapes, determining the area of rhombus, comparing the perimeter of two cloths and determining the perimeter of rhombus. Subjects were 30 first grade students of SMP Pusri Palembang. The study used a design research method consisting of three stages: preparing for the experiment, experiment in the classroom (pilot experiment and teaching experiment), and retrospective analysis. During the preparing for the experiment stage, instructional activities was designing utilizing of Indonesian Realistic Mathematics Education (PMRI) approach. The result of experiments showed that Kain Jumputan Palembang could be used as a starting point by first grade junior high school to learn rhombus.
\end{abstract}

Keywords: Kain Jumputan Palembang; rhombus; PMRl; design research.

\section{PENDAHULUAN}

Bangun datar segiempat sudah diajarkan kepada siswa sejak sekolah dasar. Bangun datar segiempat bukanlah hal baru bagi siswa, hal ini dikarenakan ada banyak contoh-contoh bangun-bangun tersebut di kehidupan seharihari siswa. Seperti yang dikemukakan Akker (2006) bahwa pada dasarnya geometri mempunyai peluang yang lebih besar untuk dipahami siswa dibandingkan dengan cabang matematika lain karena geometri sudah dikenal oleh siswa sejak mereka belum masuk sekolah seperti garis, bidang dan ruang melalui aktivi- tas sehari-hari. Namun kenyataannya menurut hasil penelitian Sudarman (2003) menunjukkan bahwa penguasaan konsep geometri siswa SD masih rendah. Madja (1992) menemukan lebih dari $55 \%$ siswa SMP mengalami kesulitan dalam mempelajari geometri. Menurut Van de Walle (2008), hasil pengujian National Assesment of Educational Progress (NAEP) menunjukkan dengan jelas bahwa siswa tidak memiliki pemahaman yang baik terhadap rumus-rumus. Kesalahan yang umum adalah tertukarnya rumus untuk luas dan keliling. Belah ketupat merupakan salah satu dari 
bangun datar tersebut.

Dalam pembelajaran matematika, telah dikenal suatu pendekatan yaitu Pendidikan Matematika Realistik Indonesia (PMRI). PMRI diadaptasi dari teori belajar mengajar Realistic Mathematics Education (RME) di Belanda. PMRI memiliki 3 prinsip yaitu 1) Petunjuk menemukan kembali/Matematisasi progresif (Guided reinvention/progressive mathematizing). Prinsip ini sejalan dengan teori ZPD Vygotsky. Menurut Vygotsky (dalam Yohanes, 2010) akan lebih baik jika siswa belajar dengan orang dewasa atau teman sebaya yang lebih mampu darinya karena melalui interaksi sosial tersebut dapat menimbulkan ide baru dan meningkatkan kemampuan intelektual siswa. 2) Fenomena yang bersifat mendidik (Didactical phenomenology). Hal ini menyebabkan dalam suatu materi matematika harus dipilihkan suatu fenomena yang dijadikan sebagai titik awal (starting point) pembelajaran. 3) Mengembangkan model sendiri (Self developed models). Kegiatan ini berperan sebagai jembatan antara pengetahuan informal dan matematika formal. Dari ketiga prinsip PMRI ini sejalan dengan aspek-aspek kegiatan pembelajaran pada KTSP. Ada tiga aspek penting dalam kegiatan pembelajaran pada KTSP yang dikenal dengan istilah eksplorasi, elaborasi dan konfirmasi. Maka PMRI sesuai dipakai dalam pembelajaran pada KTSP.

Pada pembelajaran dengan pendekatan PMRI, pembelajaran dimulai dari memberikan konteks kepada siswa yaitu dengan memberikan suatu situasi atau masalah kepada siswa. Hal ini sejalan dengan teori Bruner yang mengungkapkan bahwa dalam proses belajar anak sebaiknya diberi kesempatan untuk memanipulasi benda-benda (Tim MKPBM, 2001). Konteks nyata bermakna bagi peserta didik menurut Retnowati (2010) di suatu daerah mungkin berbeda dengan di daerah lain sehingga menggunakan konteks nyata yang tepat lebih disarankan karena akan membantu siswa untuk mempersepsikan dan mengartikan informasi lebih mudah. Penggunaan konteks budaya konsisten dengan Mathematical Sciences Education Board-National Research Council (1990; Wijaya, 2012) yang merumuskan tujuan pendidikan matematika ditinjau dari posisi matematika dalam lingkungan so- sial diantaranya tujuan budaya. Penggunaan konteks budaya telah banyak digunakan dalam penelitian antara lain dengan permainan tradisional: bermain satu rumah (Nasrullah dan Zulkardi, 2011), menggunakan anyaman (Haris dan Putri, 2011), menggunakan Math Traditional Dance (Helsa dan Hartono, 2011), menggunakan motif kain tajung Palembang (Zainab dan Zulkardi, 2013).

Berdasarkan uraian sebelumnya, peneliti menggunakan kain Jumputan Palembang sebagai starting point pemberian masalah kepada siswa dalam pembelajaran luas dan keliling belah ketupat. Siswa kelas VII dalam kurikulum KTSP mempelajari keterampilan khas daerah yang salah satunya membuat kain Jumputan. Dalam hal ini kain Jumputan adalah benda yang sudah tidak asing lagi bagi siswa dan ini akan mengitkan matematika dengan pelajaran lain. Adapun yang akan digunakan dalam penelitian ini adalah bentuk kain yang digunakan siswa untuk membuat kain Jumputan tersebut beserta motifnya. Pada kain Jumputan terdapat motif yang dapat dijadikan unit untuk membantu dalam pembelajaran luas dan keliling.

Berdasarkan pendahuluan tersebut, peneliti akan mendesain pembelajaran materi belah ketupat dengan menggunakan kain Jumputan Palembang melalui pendekatan PMRI untuk kelas VII. Adapun rumusan masalah dari pendahuluan tersebut adalah: "Apakah konteks kain Jumputan Palembang dapat membantu siswa dalam memahami konsep luas daerah dan keliling belah ketupat?" dan penelitian ini membahas penggunaan konteks kain Jumputan Palembang pada belah ketupat dan strategi siswa dalam melakukan aktifitas pembelajaran yang telah dirancang peneliti.

\section{METODE}

Metode penelitian adalah metode design research yang melalui tiga tahap yaitu preparing for the experiment, experiment in the classroom (pilot experiment dan teaching experiment), dan retrospective analysis. Proses siklik (berulang) adalah proses dari eksperimen pemikiran ke eksperimen pembelajaran dalam bentuk diagram ilustrasi ide percobaan dari Gravemeijer dan Cobb (Akker, 2006) yang ter- 
lihat di Gambar 1.

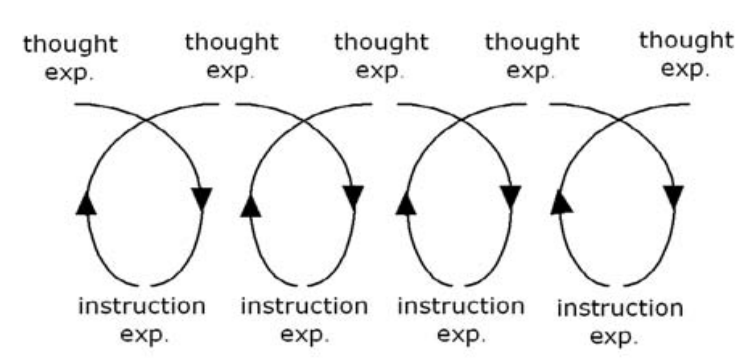

Gambar 1. Hubungan refleksif antara teori dan percobaan

Dasar dari penelitian ini adalah proses siklus yang didesain berupa dugaan pembelajaran, tes dan merevisi dugaab pembelajaran tersebut di kelas sehingga menghasilkan lintasan belajar. Dugaan tersebut dianalisis lalu didesain kembali dan direvisi kemudian diimplementasikan lagi (Gravemeijer dan Cobb, 2006). Adapun subjek penelitian ini untuk : tahap pilot experiment adalah siswa sebanyak 6 orang yang terbagi menjadi 3 kemampuan, yaitu tinggi, sedang dan rendah dan tahap teaching experiment dikelas $7 \mathrm{~B}_{1} \mathrm{SMP}$ Pusri Palembang sebanyak 30 orang. Bagian dari design research adalah pengembangan teori antara proses pembelajaran dan mendukung pembelajaran. Tahapan penelitian ini, yaitu:

\section{Preparing for the experiment}

Dalam perspektif desain, tujuan dari tahap awal dari design research adalah untuk merumuskan teori pembelajaran lokal yang dapat diuraikan ketika melakukan percobaan (Gravemeijer \& Cobb, 2006). Oleh karena itu, dalam tahap ini ide awal terinspirasi dan dijabarkan dengan mempelajari literatur seperti jurnal, artikel, dan buku-buku yang terkait dengan konsep luas daerah dan keliling belah ketupat. Selama studi literatur ini, peneliti juga mulai merancang aktifitas pembelajaran. Aktifitas pembelajaran, konjektur pemikiran dan strategi siswa dikembangkan dan berfungsi sebagai awal dari Hypothetical Learning Trajectory (HLT). Dugaan lintasan belajar ini bersifat dinamis artinya dapat diubah dan disesuaikan dengan pembelajaran yang sebenarnya sesuai dengan keadaan siswa sela- ma proses percobaan mengajar.

\section{Experiment in the classroom}

Pada tahap kedua ini dilakukan percobaan pengajaran. Menurut Gravemeijer dan Cobb (2006), tujuan dari percobaan mengajar adalah untuk menguji dan meningkatkan dugaan Local Instructional Theory (LIT) yang dikembangkan pada saat tahap awal, dan untuk mengembangkan pemahaman tentang cara kerjanya. Tujuan penelitian pengajaran ini adalah untuk mengumpulkan data untuk menjawab rumusan masalah pada penelitian. Jadi, pada tahap ini urutan aktifitas yang telah dibuat pada tahap awal dilaksanakan di dalam kelas dalam dua siklus. Siklus pertama dilakukan sebagai pilot experiment hanya mengambil 6 siswa dalam proses pembelajaran. Tujuan pilot experiment terutama untuk menyesuaikan baik isi dan urutan aktifitas yang telah dikembangkan dan memperbaikinya untuk mendapatkan desain yang lebih baik untuk siklus berikutnya yaitu teaching experiment. Kemudian, siklus kedua dilakukan sebagai proses pengajaran yang sebenarnya di mana urutan aktifitas yang dilakukan di dalam kelas. Konten matematika pada tahap percobaan mengajar pada kedua siklus ini tetap sama dimana siklus kedua adalah revisi dari siklus pertama. Sebelum melakukan percobaan mengajar, guru dan peneliti melakukan diskusi tentang aktifitas yang akan dilakukan. Peneliti menyampaikan bagaimana kegiatan pembelajaran akan dilangsungkan, sementara guru juga memberi masukan atas aktifitas yang akan ataupun yang telah dilakukan.

\section{Retrospective Analysis}

Didalam retrospective analysis, HLT digunakan sebagai pedoman dan titik referensi dalam menganalisis seluruh data yang dikumpulkan selama percobaan pengajaran. HLT ini dibandingkan dengan teori yang sebenarnya dan proses pembelajaran siswa yang terjadi di dalam kelas. Deskripsi analisis tidak hanya mengenai hal-hal yang mendukung dugaan tapi juga yang bertentangan dengan dugaan. Kesimpulan dari analisis ini digunakan sebagai jawaban dari rumusan masalah pen- 
elitian. Pada tahap persiapan, fungsi HLT sebagai pedoman untuk merancang bahan ajar yang harus dikembangkan. Dalam percobaan mengajar, fungsi HLT sebagai pedoman bagi guru dan peneliti untuk menentukan fokus dari kegiatan pembelajaran, wawancara, dan kegiatan observasi. Dalam fase retrospective analysis, HLT berfungsi sebagai pedoman bagi peneliti untuk memutuskan fokus analisis.

\section{HASIL DAN PEMBAHASAN}

Proses pembelajaran yang berlangsung terdiri dari beberapa aktifitas. Sebelum dan sesudah aktifitas dilakukan tes awal dan tes akhir yang bertujuan untuk mengetahui kemampuan pemahaman konsep siswa. Adapun aktifitas yang dilakukan adalah sebagai berikut:

\section{Aktifitas 1 : membandingkan luas daerah dua buah kain jumputan}

Adapun tujuan dari aktifitas ini adalah siswa dapat mengeksplorasi pengetahuan bahwa ada keterkaitan antara matematika dengan pelajaran lain, dalam hal ini pelajaran keterampilan khas daerah yakni membuat kain jumputan. Melalui aktifitas ini siswa dapat membandingkan luas daerah kedua kain jumputan dan siswa dapat menyatakan bahwa kedua kain tersebut memiliki luas yang sama namun bentuknya berbeda.

Pada aktifitas ini siswa diberikan lembar aktifitas 1 dan didiskusikan secara berkelompok. Masing-masing kelompok terdiri dari 5 orang. Pada aktifitas ini, siswa juga dibagikan dua buah kain Jumputan Palembang yang berbentuk persegi panjang dan belah ketupat. Siswa diminta membandingkan luas daerah kedua kain tersebut.

Guru beserta peneliti sebagai observer berkeliling melihat jalannya diskusi di tiap kelompok untuk membantu kelompok yang menemukan kesulitan dalam mengerjakan lembar.aktifitas sekaligus mengetahui ide-ide yang muncul dari tiap-tiap kelompok. Salah satunya pada kelompok 2. Observer menanyakan bagaimana cara kelompok 2 menyelesaikan lembar aktifitas 1. Hal ini tergambar pada percakapan berikut.

$\begin{array}{ll}\text { Siswa } & \text { : Bentuknya sama } \\ \text { Observer } & : \text { Sama?Gimana kamu tahunya } \\ \text { UNNDS } & \text { JDIRNALS }\end{array}$

\begin{tabular}{|c|c|}
\hline \multirow{3}{*}{ Siswa } & sama? \\
\hline & : (sambil menunjuk ke bagian kain) \\
\hline & $\begin{array}{l}\text { Yang ini kan bisa digabungin kesi- } \\
\text { ni, untuk jadi satu persegi, yang } \\
\text { ini gabung kesini jadi persegi, jadi } \\
\text { ada enam kotak sama seperti ini }\end{array}$ \\
\hline Observer & : Jadi kesimpulan kamu apa? \\
\hline Siswa & $\begin{array}{l}\text { : Kesimpulannya jadi bentuknya } \\
\text { sama, membutuhkan bahan dasar } \\
\text { sama }\end{array}$ \\
\hline Observer & $\begin{array}{l}\text { :Yang ini tadi jumlah Ko- } \\
\text { taknya berapa? (menunjuk ke kain } \\
\text { yang berbentuk persegi panjang) }\end{array}$ \\
\hline Siswa & $: 12$ \\
\hline Observer & $\begin{array}{l}\text { : Yang ini? (sambil menunjuk kain } \\
\text { yang berbentuk belah ketupat) }\end{array}$ \\
\hline Siswa & $\begin{array}{l}\text { : } 12 \text { juga, ini kan } 2 \text { kotak, ini } 2 \text { kotak, } \\
\text { jadi } 4 \text { kotak, } 6 \text { kotak, } 8 \text { kotak,10 }\end{array}$ \\
\hline & kotak, ini digabung sini jadi 12 \\
\hline
\end{tabular}

Lalu observer juga ke kelompok 3 dan juga menanyakan cara mereka menyelesaikan aktifitas 1. Hal ini tergambar pada percakapan berikut.

$\begin{array}{ll}\text { Observer } & \text { :Teknik } \\ \text { digunain?Ditumpuk ya? } & \text { : lya } \\ \text { Observer } & \text { : Ide siapa tadi? } \\ \text { Siswa } & \text { : Afifah } \\ \text { Observer } & \text { :Ok, bisa dijelaskan Afifah? Intinya } \\ & \text { menurut kalian yang mana yang } \\ & \text { lebih banyak? Atau sama? Atau } \\ & \text { bagaimana kedua kain ini? } \\ \text { Siswa } & \text { : sama } \\ \text { Observer } & \text { : Ok, bisa dijelasin gak Afifah? } \\ \text { Siswa } & \text { :Soalnyo ini kalo digabungin jadi } \\ & \text { segitiga, yang sebelah sini kalo di- } \\ & \text { gabungin jadi segitiga (sambil me- } \\ & \text { nunjuk ke bagian kain) }\end{array}$

Dari hasil bertanya pada dua kelompok tersebut ternyata strategi yang digunakan adalah menghitung motif dan menumpuk kain. Setelah seluruh kelompok menyelesaikan lembar aktifitas 1, maka guru menunjuk kelompok 5 untuk menyajikan hasil jawaban mereka ke depan kelas. Kemudian memberi kesempatan pada kelompok 3 yang memiliki strategi berbeda dengan kelompok 5 untuk menyajikan juga hasil jawabannya di depan kelas. 


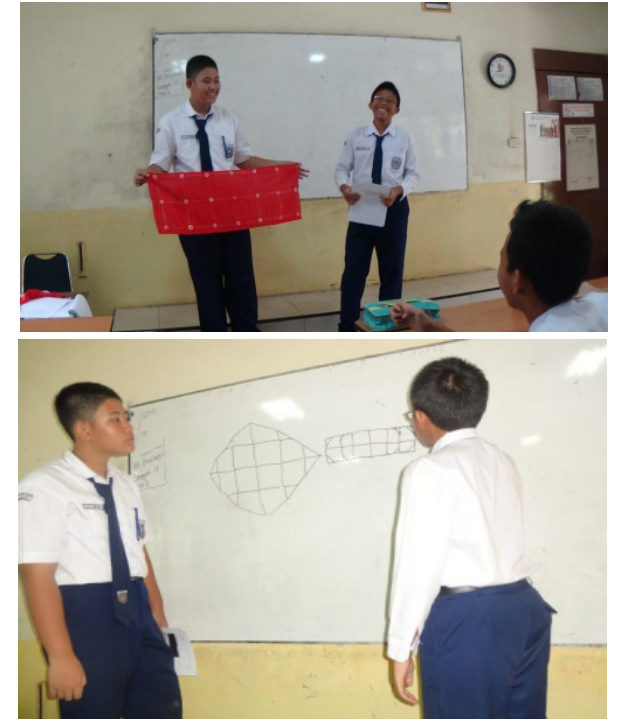

Gambar 2. Presentasi kelompok 5 untuk LAS 1

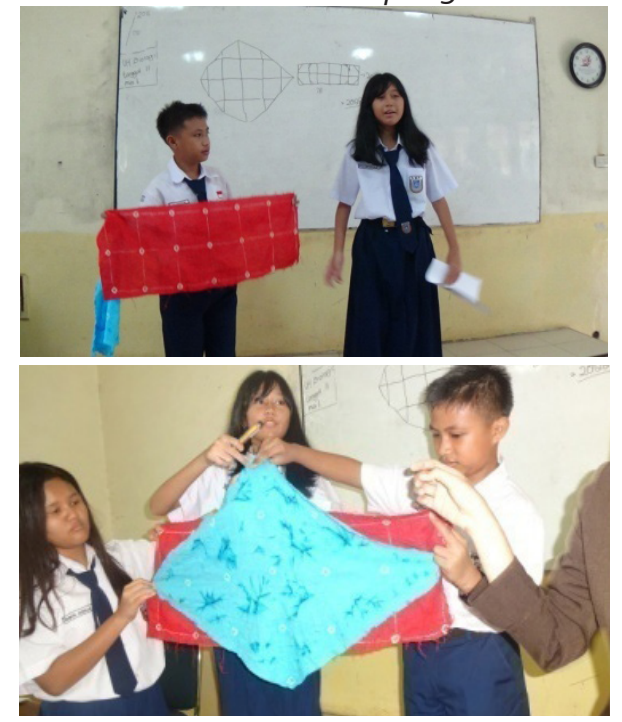

Gambar 3. Presentasi kelompok 3 untuk LAS 1

\section{Aktifitas 2 : Membentuk potongan belah ketupat menjadi bentuk-ben- tuk lain}

Tujuan pembelajaran pada aktifitas 2 ini, siswa dapat merancang ukuran belah ketupat sesuai perintah dengan tepat, menggambarnya dengan tepat, mengguntingnya menjadi empat segitiga yang kongruen, dan menyusunnya kembali menjadi bentuk-bentuk bangun datar yang lain. Tujuan khusus dari aktifitas ini adalah siswa dapat menemukan bangun-bangun datar baru yang dibentuk dari potongan-potongan bentuk belah ketupat dan mengetahui bahwa luas daerah belah ketupat yang mereka buat, sama dengan luas daerah bangun- bangun baru yang mereka bentuk/temukan/ susun.

Pada aktifitas ini, siswa dibagikan LAS 2 dan tetap didiskusikan bersama kelompok. Siswa diminta untuk merancang belah ketupat dengan perbandingan diagonal-diagonalnya 1 : 3 . Kemudian siswa diminta untuk menggambarnya diatas kertas kambing yang telah disediakan. Setelah itu, siswa diminta untuk menggunting belah ketupat tersebut menjadi empat segitiga yang kongruen. Terakhir, siswa diminta untuk menyusun kembali segitiga-segitiga tersebut menjadi bentukbentuk yang baru.

Guru bersama peneliti yang dalam hal ini sebagai observer berkeliling untuk melihat jalannya diskusi siswa di tiap kelompok sekaligus melihat strategi yang mereka gunakan untuk menyelesaikan lembar aktifitas 2. Pada aktifitas 2 ini, siswa merancang gambar belah ketupat, kemudian menggambarnya dan mengguntingnya. Ternyata selain cara menggambar dan menggunting yang biasa dilakukan, peneliti menemukan pada kelompok 3 yang tidak langsung menggambar dan menggunting langsung satu belah ketupat namun menggambar dan menggunting 1 segitiga terlebih dahulu. Hal ini tergambar pada percakapan berikut.

Observer: Oh ini teknik membuat belah ketupat ya?jadi separoh dulu?baru nanti separoh lagi?

Siswa : lya

Setelah seluruh kelompok menyelesaikan diskusinya dan mendapat jawaban, guru menunjuk kelompok 2 untuk menyajikan hasil diskusinya didepan kelas yang dituliskan di papan tulis. Setelah kelompok 2 menyajikan hasil jawabannya, kelompok 5 diperkenankan untuk menambahi karena ada bentuk temuan mereka yang berbeda dengan kelompok 2 . 

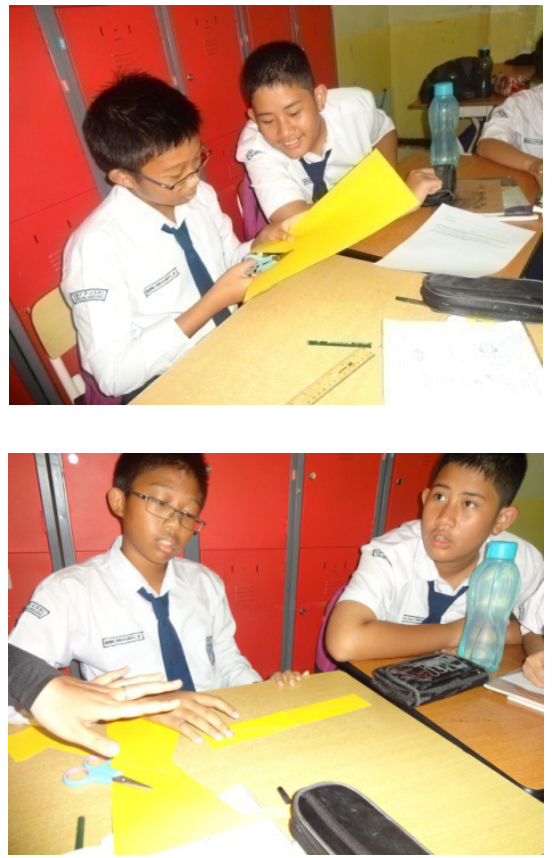

Gambar 4. Kelompok 5 mengerjakan LAS 2
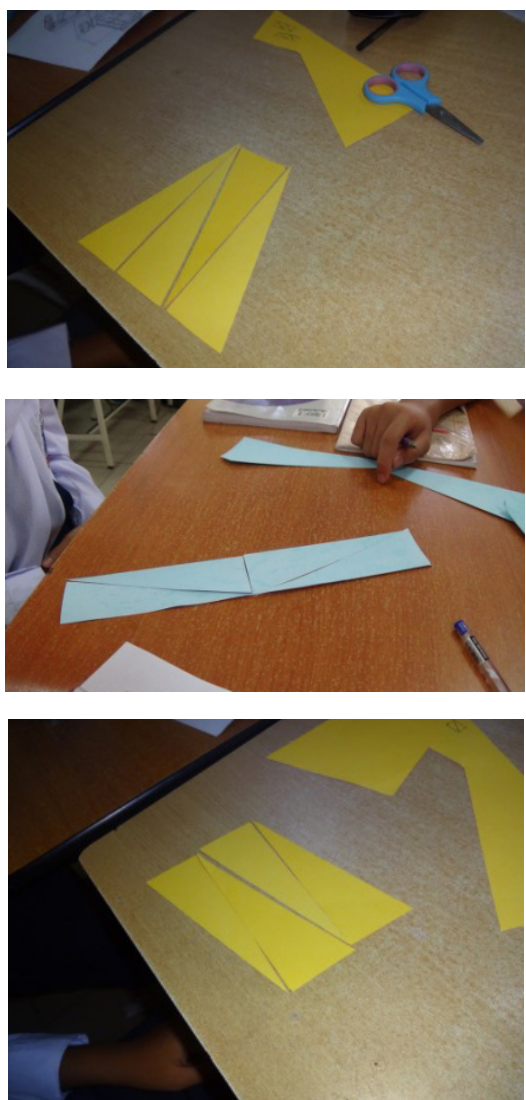

Gambar 5. Beberapa hasil diskusi siswa dari LAS 2
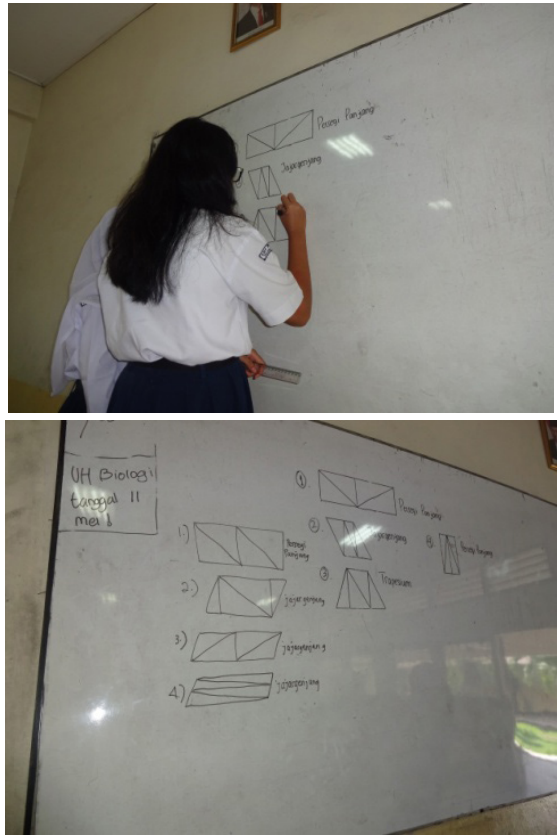

Gambar 6. Hasil presentasi untuk LAS 2

Setelah presentasi, guru bersama-sama siswa membuat kesimpulan dari pembelajaran. Hal ini tergambar pada percakapan berikut.

Guru : Setelah diubah-ubah, dibentuk jadi bangun yang lain, luasnya bagaimana?

Siswa : Sama

Guru : Sama? Bener sama? Pasti sama... kenapa pasti sama?(siswa menjawab beramai-ramai) ntar satu orang, (guru menunjuk satu orang) kenapa tadi?

Siswa : Kan ukuran belah ketupat tadi dibagi menjadi empat segitiga yang sama persis, jadi kalo dibentuk jadi bangun lain pasti juga sama

Guru : oke,jadi mau bentuknya papun, kalo dari awalnya sama pasti sama

\section{Aktifitas 3 : Menentukan luas belah ketupat menggunakan pendekatan persegi panjang}

Tujuan pembelajaran pada aktifitas 3 ini adalah siswa dapat menemukan formula luas daerah belah ketupat dengan menggunakan pendekatan luas daerah persegi panjang.

Pada aktifitas ini, siswa berdiskusi didalam kelompok untuk menyimpulkan bagaimana menentukan luas daerah belah ketupat dengan menggunakan pendekatan luas persegi panjang. Seperti pada pembelajaran se- 
belumnya, guru bersama peneliti yang dalam hal ini sebagai observer, berkeliling melihat jalannya diskusi siswa serta membantu siswa yang mengalami kesulitan dalam menjawab seperti pada kelompok 1. Hal ini tergambar pada percakapan berikut.

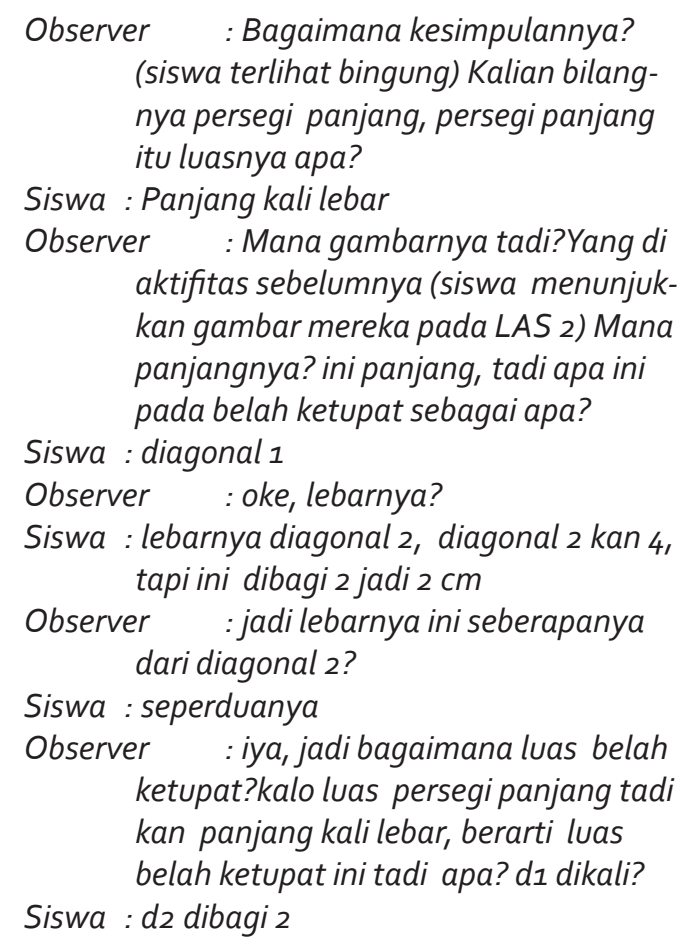

Setelah semua kelompok selesai mengerjakan LAS 3, maka guru langsung memandu siswa untuk menyajikan jawaban mereka sekaligus mendapatkan kesimpulan dari pembelajaran luas daerah belah ketupat. Hal ini tergambar pada percakapan berikut.

\begin{tabular}{|c|c|}
\hline Guru & : Satu orang angkat tangan ok alya? \\
\hline Alya & :Persegi panjang \\
\hline Guru & $\begin{array}{l}\text { : Persegi panjang, kenapa ya'?jadi luas- } \\
\text { nya? }\end{array}$ \\
\hline Alya & $\begin{array}{l}\text { : setengah diagonal } 1, \text { terus diagonal } 2 \\
\text { semuanya miss, }\end{array}$ \\
\hline Guru & $\begin{array}{l}\text { : Ada yang bisa bikin jadi simple } \\
\text { rumusnya?ok, Hilman }\end{array}$ \\
\hline Hilmar & $\begin{array}{l}\text { : Rumus yang no } 2 \text { kan miss? d1 dikali } \\
\text { setengah dikalid2 }\end{array}$ \\
\hline Guru & : ok, atau mehra? \\
\hline Mehra & : dı kali d2 bagi 2 \\
\hline Guru & $\begin{array}{l}\text { : Good, gampang kan? Karena setengah } \\
\text { itu bisa dikalikan ke d1 bisa dikalikan } \\
\text { dengan d } 2\end{array}$ \\
\hline
\end{tabular}

\section{Aktifitas 4 : Menyelesaikan masalah yang berkaitan dengan luas belah ketupat}

Tujuan dari aktifitas 4 ini adalah melihat kemampuan individu siswa dalam menyelesaikan masalah-masalah yang berkaitan dengan luas daerah belah ketupat.

Pada aktifitas ini, siswa diberikan tiga masalah yang berkaitan dengan luas daerah belah ketupat. Pada soal pertama, sebagian siswa sudah menjawab dengan benar dan langsung menggunakan rumus luas daerah belah ketupat yang sudah mereka dapatkan pada aktifitas sebelumnya. Pada soal kedua ini lebih dari separuh kelas sudah bisa menjawab dengan benar dan muncul keberagaman jawaban siswa dikarenakan soal ini bertipe soal yang memiliki banyak jawaban (lebih dari satu jawaban). Pada soal ketiga hampir semua siswa menjawab benar. Walaupun jawaban akhirnya sama, tapi masing-masing siswa mempunyai cara yang berbeda-beda dalam menjawabnya.

\section{Aktifitas 5 : Membandingkan kelil- ing dua kain jumputan yang luasnya sama}

Tujuan pembelajaran dari aktifitas 5 ini adalah menanamkan konsep pada siswa bahwa satu bentuk bangun datar yang diubah bentuk menjadi bangun lain maka luasnya tetap namun kelilingnya berubah. Aktifitas ini juga menekankan pada siswa bahwa untuk dua bangun datar yang berbeda bentuk namun luasnya sama, kelilingnya tidak lantas sama juga.

Pada aktifitas ini, siswa kembali diberikan dua buah kain Jumputan seperti pada aktifitas 1. Namun kali ini siswa diminta untuk menjawab kain mana yang memerlukan benang lebih banyak jika kedua kain disekelilingnya akan dijait jelujur. Untuk menjawabnya, siswa juga diberikan benang dan mistar.

Guru bersama observer berkeliling untuk melihat pekerjaan siswa, melihat strategi apa yang mereka lakukan dalam mengerjakan LAS 5 . Hal ini tergambar pada percakapan berikut. 


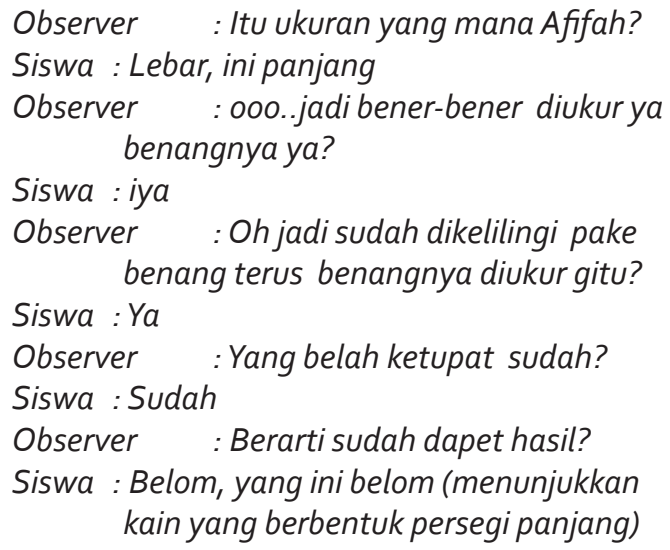

Percakapan diatas terjadi pada kelompok 3 yang menggunakan 2 benang (tiap kain 1 benang) kemudian dibandingkan. Berbeda halnya dengan kelompok 3 , kelompok 2 hanya menggunakan satu benang untuk membandingkan keliling kedua kain tersebut. Hal ini tergambar pada percakapan berikut.

Guru :Yang ini sudah diukur?

Siswa : Udah, jadi patokannya miss

Observer :Oh..gimana? bisa dijelasin? Nabil jelasin tadi pertama-tama yang dikerjakan apa?

Siswa : Itu ngukur persegi panjangnya pake benang,

Observer : Kemudian?

Siswa : Diukur penuh, nah hasilnya benang itu dicobakan kebelah ketupat

Observer : Ok, hasil benang yang pada persegi panjang, kalian cobakan pada belah ketupat hasilnya ternyata?

Siswa : Lebih

\section{Aktifitas 6 : Menentukan keliling be- lah ketupat}

Tujuan dari aktifitas 6 ini adalah menggiring siswa untuk menemukan rumus keliling belah ketupat. Pada aktifitas kali ini, siswa diminta untuk berdiskusi dalam menentukan keliling belah ketupat. Guru dan observer memantau jalannya diskusi siswa sekaligus mengarahkan jawaban siswa seperti yang terjadi pada kelompok 6 . Hal ini tergambar pada percakapan berikut.

\footnotetext{
Observer : Itu apa yang lagi dilakukan?

Siswa : Eeee...nyari diagonal

Observer : Ntar, kan yang dibilang keliling, tadi waktu mengelilingi pake diagonal gak?
}

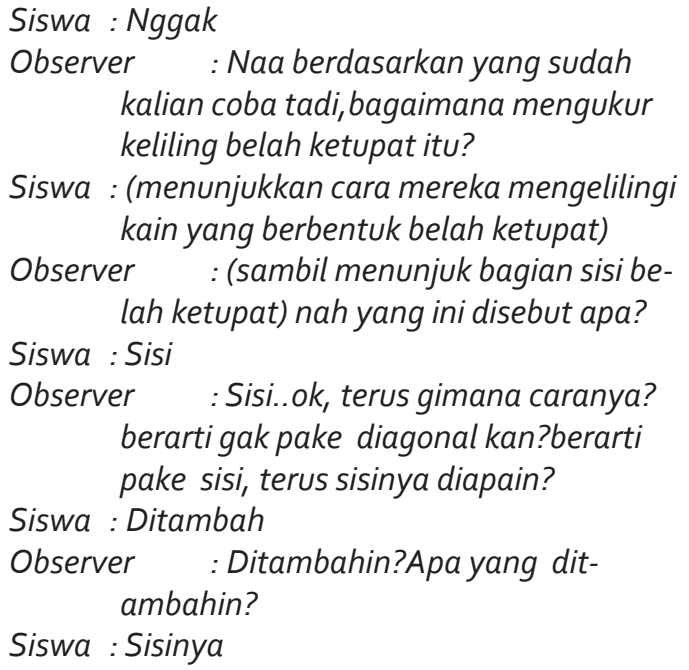

Jika pada kelompok 6 diatas siswa akhirnya menemukan cara "ditambahkan sisinya" maka berbeda dengan kelompok 3. Hal ini tergambar pada percakapan berikut.

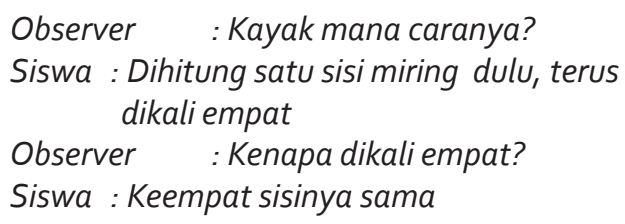

Di akhir pembelajaran, guru meminta beberapa kelompok untuk menyajikan hasil diskusinya. Setelah mendengar pendapat semua kelompok, guru bersama-sama siswa menarik kesimpulan tentang apa yang sudah dipelajari.

\section{Aktifitas 7 : Menyelesaikan masalah yang berkaitan dengan keliling belah ketupat}

Tujuan dari aktifitas 7 ini adalah melihat kemampuan individu siswa dalam menyelesaikan masalah-masalah yang berkaitan dengan keliling belah ketupat. Pada aktifitas ini, siswa diberikan 3 masalah yang berkaitan dengan keliling belah ketupat. Pada soal pertama, hampir seluruh siswa sudah bisa menjawab dengan benar. Hanya beberapa siswa saja yang masih menjawab salah, ini pun karena mereka kurang teliti dalam menghitung saja. Pada soal kedua ini juga hampir seluruh siswa sudah menjawab benar. Baik itu menggunakan rumus $4 \times s$ maupun rumus $s+s+s+s$, 
ada juga yang langsung membagi keliling dibagi 4 . Kesalahan hanya pada saat menggambar, namun untuk perhitungan sudah benar.

Untuk soal ketiga pun demikian, hampir seluruh siswa sudah bisa menjawab dengan benar, rumus yang digunakan juga seperti pada soal kedua, dan kesalahannya pun hanya kurang teliti dalam perhitungan saja.

Dari hasil design research yang telah dilakukan, diperoleh lintasan belajar belah ketupat menggunakan kain Jumputan Palembang dengan pendekatan PMRI dilakukan di kelas VII. Selain itu, diperoleh strategi-strategi pemikiran siswa dalam menyelesaikan materi belah ketupat. Strategi tersebut merupakan dampak dari penerapan HLT yang telah didesain dan diujicobakan pada tahap pilot experiment, kemudian direvisi sehingga dapat diterapkan pada teaching experiment yang menghasilkan LT. Pembelajaran yang dilaksanakan menggunakan konteks kain Jumputan Palembang sebagai starting point untuk mengawali materi belah ketupat. Motif dan bentuk kain Jumputan yang diberikan membantu siswa dalam mempelajari materi tersebut. Untuk mendukung konteks tersebut, maka pendekatan PMRI berperan sangat besar dalam proses pembelajaran yang berlangsung lebih aktif dan efisien.

Semua ide atau strategi yang siswa temukan, tuliskan, gambarkan, diskusikan, menunjukkan adanya konstribusi siswa dalam membantu pemahaman siswa dalam pembelajaran belah ketupat. Aktifitas siswa dalam pembelajaran juga sesuai dengan karakteristik PMRI. Adapun karakteristik PMRI pada aktifitas penelitian ini adalah sebagai berikut: (a) Menggunakan masalah kontekstual, yaitu matematika sebagai kegiatan sehari-hari, sehingga siswa dapat memecahkan masalah yang dialaminya menggunakan matematika. Siswa mengamati dan menganalisis bentuk dan motif kain Jumputan pada gambar 4.3 untuk mencari luas dan kelilingnya. Siswa membangun pengetahuannya sendiri, bukan hanya sekedar mengingat atau menghafal; (b) Menggunakan model, yaitu model belajar matematika berarti bekerja dengan matematika. Siswa merancang dan membuat belah ketupat dengan menggunakan kertas kambing kemudian mengguntingnya dan menyusunnya kembali menjadi suatu bentuk yang baru sehingga siswa yakin bahwa luas daerah belah ketupat awal dengan luas daerah bentuk yang baru dibentuk atau disusun adalah sama; (c) Menggunakan hasil dan konstruksi siswa sendiri, yaitu siswa diberikan kesempatan untuk menemukan konsep-konsep matematika dengan bimbingan guru. Siswa dengan bimbingan guru menentukan luas daerah dan keliling belah ketupat; (d) Pembelajaran terfokus pada siswa. Proses pembelajaran terfokus pada aktifitas-aktifitas yang dikerjakan oleh siswa. Jadi selama proses pembelajaran berlangsung, siswalah yang aktif melakukan aktifitas sementara guru hanya menjadi fasilitator yang membimbing siswa dan membantu siswa menarik kesimpulan; (e) Terjadi interaksi antara guru dan siswa. Pada pembelajaran ini, aktifitas terfokus dikerjakan oleh siswa, guru dalam hal ini menjadi fasilitator dalam membantu siswa memecahkan masalah, disini terjadi interaksi antara guru dan siswa. Kemudian guru juga membantu siswa menarik kesimpulan saat siswa selesai menyajikan hasil aktifitasnya, maka saat itu juga terjadi interaksi antara guru dan siswa.

\section{SIMPULAN}

Design research yang merupakan pengembangan LIT pada belah ketupat dengan menggunakan kain jumputan Palembang dapat membantu siswa dalam memahami konsep luas daerah dan keliling belah ketupat. Motif dan bentuk kain Jumputan Palembang yang digeneralisasikan pada kertas kambing dapat membantu siswa dalam menemukan strategi yang digunakan. Pengembangan belah ketupat menggunakan konteks yang nyata diharapkan dapat membantu dalam mengembangkan strategi berfikir siswa untuk mengemukakan idea atau gagasan dalam menyelesaikan pemecahan masalah.

\section{DAFTAR PUSTAKA}

Abdussakir, A. (2012). Pembelajaran Geometri Sesuai Teori Van Hiele. Madrasah, 2(1).

Akker, et al. (2006). Education design research. London: Routledge Taylor and Francis Group.

Gravemeijer, K., \& Cobb, P. (2006). Design research from the learning design perspective. In Van den Akker, J., Gravemerijer, K., McKenney, S., \& Nieveen, $N$ (Eds.), Educational design research. 
40 Fauziyah et al, Desain Pembelajaran Materi Belah Ketupat Menggunakan Kain Jumputan ...

London: Routledge.

Haris, D. and Putri, RII. (2011). The Role of Context in Third Graders Learning of Area Measurement. IndoMS. J.M.E, 2(1), 55-66.

Helsa, Y. \& Hartono, Y. (2011). Designing reflection and symmetry learning by using math traditional dance in primary school. IndoMS JME, 2(1), 7994.

Madja, M.S. (1992). Perancangan dan Implementasi Perangkat Ajar Geometri SMTA. Tesis tidak diterbitkan. Jakarta: PPS UI.

Nasrullah \& Zulkardi. (2011). Building counting by traditional game: a mathematics program for young children. IndoMS JME, 2(1), 41-54.

Retnowati, E. (Juli. 2010). Pendidikan matematika realistik: Sebuah tinjauan teoritik. Majalah PMRI/vol. viii No. 3/Juli 2010. Bandung: Institut Pengembangan Pendidikan Matematika Realistik Indonesia (IP-PMRI).

Sudarman. (2003). Pengembangan Paket Pembelajaran
Berbantuan Komputer Materi Luas dan Keliling Segitiga untuk Kelas V Sekolah Dasar. Tesis tidak diterbitkan. Universitas Negeri Malang, Malang.

Tim MKPBM. (2001). Strategi Pembelajaran Matematika Kontemporer. Bandung: JICA-Universitas Pendidikan Indonesia

Van de Walle, John. A. (2008). Matematika Sekolah Dasar dan Menengah. Jakarta: PT. Erlangga.

Wijaya, A. (2012). Pendidikan matematika realistik: Suatu alternatif pendekatan pembelajaran matematika. Yogyakarta: Graha Ilmu.

Yohanes, R. S. (2010). Teori Vygotsky Dan Implikasinya Terhadap Pembelajaran Matematika. Widya Warta No. 02 Tahun XXXIV, 127-135.

Zainab, Zulkardi, \& Yusuf, H. (2013). Desain Pembelajaran Materi Pola Bilangan Dengan Pendekatan PMRI Menggunakan Kerajinan Tradisional Kain Tajung Palembang Untuk Kelas IX SMP. Jurnal Edukasi Matematika, 4(7). 